\title{
Winter distribution and possible migration routes of humpback whales Megaptera novaeangliae in the southwest Indian Ocean
}

\author{
P. B. Best ${ }^{1, *}$, K. P. Findlay ${ }^{1, * *}$, K. Sekiguchi ${ }^{1, * * *}$, V. M. Peddemors ${ }^{2}$, B. Rakotonirina ${ }^{3}$, \\ A. Rossouw ${ }^{1}$, D. Gove ${ }^{4}$ \\ ${ }^{1}$ Mammal Research Institute, Whale Unit (University of Pretoria), c/o S. A. Museum, PO Box 61, Cape Town, 8000 South Africa \\ ${ }^{2}$ Natal Sharks Board, Private Bag 2, Umhlanga, Kwazulu-Natal, 4320 South Africa \\ ${ }^{3}$ Institut Halieutique et des Sciences Marines, Université de Toliara, Madagascar \\ ${ }^{4}$ Dept of Biological Sciences, University of Eduardo Mondlane, PO Box 257, Maputo, Mozambique
}

\begin{abstract}
The distribution and seasonality of humpback whales Megaptera novaeangliae in the southwest Indian Ocean are investigated from a number of sources. These include sighting and acoustic data collected on shore-based surveys on the African coast and from dedicated ship-based surveys in the coastal waters of Mozambique, Madagascar, across the Mozambique Channel and along the Madagascar Ridge, plus aerial sighting data from the Durban (South Africa) whaling ground, historical catch data by $10 \mathrm{~d}$ period for whaling operations at Durban, Linga Linga (Mozambique) and Madagascar, and incidental sightings data from a research ship and transiting merchant vessel. Three principal migratory routes are proposed. The first ('East African') strikes and leaves the African coast at least as far west as Knysna $\left(23^{\circ} \mathrm{E}\right)$. The number and timing of peak abundances at Durban, Cape Vidal (South Africa) and Linga Linga suggest that this migration continues as far as central Mozambique, where abundance peaked in the first $10 \mathrm{~d}$ of August, and is slower and more protracted on the way south than on the way north. The second route ('Madagascar Ridge') supplies the coast of Madagascar directly from the south, probably via the Madagascar Ridge. The seasonality of catches in modern whaling in southern Madagascar implies that this migration proceeds somewhat further north, and one nineteenth-century whaling ground was on the northeastern coast of Madagascar at $15^{\circ} 30^{\prime} \mathrm{S}$. The existence of the third migratory route ('Central Mozambique Channel') is based principally on the discovery of singing humpback whales in the centre of the Mozambique Channel in July/August and September, separate from contemporary singers on the continental shelves of Mozambique and Madagascar The winter destınation of this route may be the Comores Islands and Aldabra, where there have been a number of recent sightings.
\end{abstract}

KEY WORDS: Humpback whale - Migration Indian Ocean

\section{INTRODUCTION}

Humpback whales Megaptera novaeangliae are baleen whales that undertake seasonal migrations between summer feeding grounds in high latitudes of

\footnotetext{
•E-mail: pbest@samuseum.ac.za

Present addresses:

- Oceanography Dept, University of Cape Town, Rondebosch, 7700 South Africa

*450 Ka'aninı Circle. Hilo, Hawaii 96720, USA

both hemispheres to winter breeding grounds in tropical or subtropical waters. While the timing and pattern of migrations are known in general for southern humpback whales (Dawbin 1966), and the routes and destinations in some detail for humpback whales in the Australasian region (Dawbin 1956, Chittleborough 1965), much speculation remains for other areas of the southern hemisphere, particularly the western Indian and South Atlantic Oceans. Mackintosh (1942) postulated an 'African group' that summered between $10^{\circ}$ and $40^{\circ} \mathrm{E}$ in the Antarctic and wintered off Madagas- 
car, in East African waters and possibly on the west coast of South Africa: the only direct evidence for this came from 2 whales marked in the Antarctic lat $54^{\circ} 03^{\prime} \mathrm{E}$ and $10^{\circ} 41^{\prime} \mathrm{E}$ ) and subsequently killed south of Madagascar (Rayner 1940).

In this paper several original sources of data are examined in an attempt to describe migratory routes and winter destinations for humpback whales in the southwest Indian Ocean. These include a shipboard survey for whales in the southwest Indian Ocean from November 1973 to February 1974; sightings from the spotter aircraft attached to the Durban (South Africa) whaling station from 1972 to 1975; systematic shorebased surveys for humpback whales at Cape Vidal (South Africa), 1988 to 1991; shipboard sighting and acoustic surveys for humpback whales in the coastal waters of Mozambique (1991) and Madagascar (1994) and across the Mozambique Channel (1994); a ship- board survey for blue whales along the Madagascar Ridge (1996); and incidental observations at Walters Shoal (south of Madagascar) in December 1988, and from the Knysna Heads (southern coast of South Africa) between 1903 and 1906. Additionally, catch data are reviewed for indications of seasonality.

\section{MATERIAL AND METHODS}

Between 1903 and 1906, observations of whales were made by the Harbour Pilot from the Knysna Heads, on the southern coast of South Africa (Fig. 1), about $100 \mathrm{~m}$ above sea level, possibly as part of a scheme to introduce commercial whaling in the area. Best \& Ross (1996) have discussed the reliability of these observations, which included records of a total of at least 667 humpback whales over 4 years. They con-

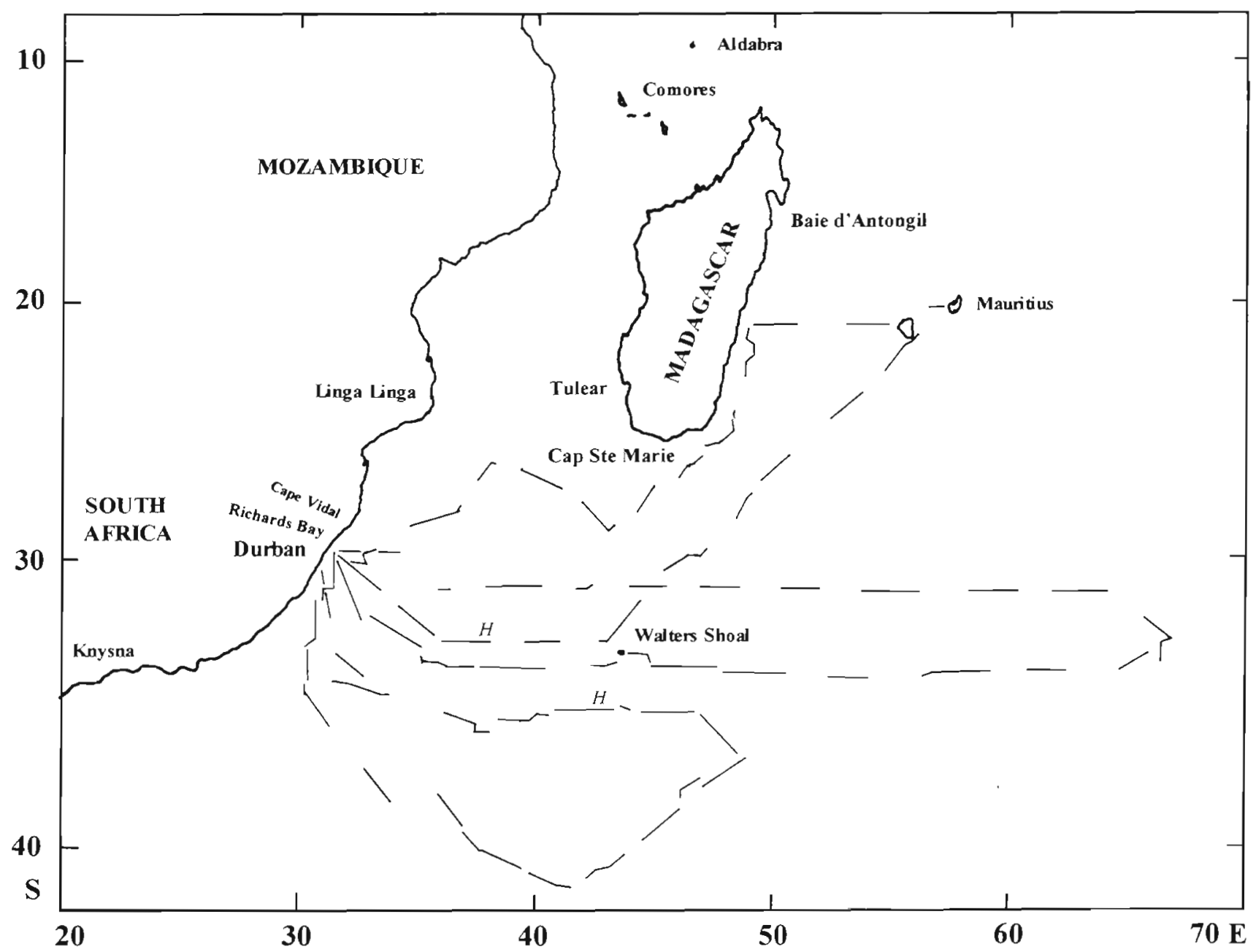

Fig. 1. Southwest Indian Ocean, showing the cruise track during daylight hours of the 'Pieter Molenaar', 24 November 1973 to 3 February 1974. H: sighting of humpback whale 
cluded that there was no good reason to doubt the validity of the identifications of the right and humpback whales reported.

Between 24 November 1973 and 3 February 1974 , the Durban whale-catcher 'Pieter Molenaar' was chartered by relevant government agencies in Australia, South Africa, UK and USA for a whale-marking and sighting cruise. Three separate transects were steamed in the western Indian Ocean out of Durban, one between $20^{\circ}$ and $33^{\circ} \mathrm{S}, 30^{\circ}$ and $57^{\circ} \mathrm{E}$, the second between $35^{\circ}$ and $42^{\circ} \mathrm{S}, 30^{\circ}$ and $49^{\circ} \mathrm{E}$, and the third between $31^{\circ}$ and $34^{\circ} \mathrm{S}, 30^{\circ}$ and $67^{\circ} \mathrm{E}$ (Fig. 1). The methodology and general results of the cruise are given by Gambell et al. (1975).

Daily charts giving the flight path searched and the positions of associated whale sightings made by the spotter aircraft working for the Union Whaling Company, Durban, were available for 628 flights between 1972 and 1975. This material amounted to some $430000 \mathrm{n}$ miles of searching between the months of February and October. The altitude and speed of the spotter aircraft (a Cessna 310) were usually $500 \mathrm{ft}$ and 135 knots, and 1 spotter was carried besides the pilot. Effort and sightings data were analysed by $10 \mathrm{~min}$ square of longitude and latitude, and densities (or 'encounter rates') calculated as the number of whales seen per n mile searched (Findlay 1989).

In December 1988 the oceanographic research ship 'Vityaz' of the P. P. Shirshov Institute of Oceanology, Moscow, Russia, visited the Walters Shoal, a relatively shallow area about $400 \mathrm{n}$ miles south of Madagascar between $32^{\circ}$ and $34^{\circ} \mathrm{S}, 43^{\circ}$ and $45^{\circ} \mathrm{E}$, with average soundings around $500 \mathrm{~m}$ and occasionally shallower areas (Fig. 1). Incidental observations of humpback whales were made by Nigel Merrett of the Natural History Museum, London, UK.

From 1988 to 1992, shore-based surveys of humpback whales were undertaken at Cape Vidal in northern Natal, South Africa (Findlay \& Best 1996a, b). Groups were tracked by theodolite from either 1 or 2 towers on a coastal sand dune about $60 \mathrm{~m}$ above sea level. When a boat was available, groups of humpback whales were intercepted from the shore. During these launches, acoustic stations were held periodically by lowering an omnidirectional hydrophone (custom-built by the Institute of Maritime Technology, Simons Town, South Africa) from the stationary boat to a depth of $5 \mathrm{~m}$, with a cable about $10 \mathrm{~m}$ long running to the boat. In total, 68 acoustic stations lasting from 4 to 82 min each were held (Table 1).

A $20 \mathrm{~m}$ yacht, 'Zanj' was chartered for a survey of the coastal waters (out to the $183 \mathrm{~m}$ isobath) of southern and central Mozambique between $18^{\circ}$ and $26^{\circ} \mathrm{S}$ in August/September 1991 (Findlay et al. 1994), and for a survey of the Mozambique Channel and coastal waters of southern Madagascar south of $22^{\circ} \mathrm{S}$ in August/September 1994 (Best et al. 1996). Systematic watches for cetaceans were held, weather permitting, from a lookout position on the mast $10 \mathrm{~m}$ above sea level, or from the coachhouse roof. Distances to sightings were estimated by taking photographs from the masthead lookout position that included the horizon and the whale, and angles/bearings to sightings were determined using an angleboard or an electronic compass linked to the distance-estimation camera. Densities of humpback whales and resultant population estimates were obtained using line transect methodologies (Findlay et al. 1994, Best et al. 1996). As part of these surveys, regular acoustic stations were held when the yacht was stationary (either at anchor or drifting), and with the engine and other moving machinery shut down. An omnidirectional hydrophone was lowered from the stern to a depth of about $5 \mathrm{~m}$ (1991) or $7.8 \mathrm{~m}$ (1994), with a cable $10 \mathrm{~m}$ in length running from the floats supporting the hydrophone to the yacht. Two different hydrophones were used; both were custom-built units assembled by the Institute of Maritime Technology, Simons Town. Acoustic stations lasted for between 4 and $70 \mathrm{~min}$, although the majority (40) were 8 to $12 \mathrm{~min}$ long. Most were held in the early morning, at or just after dawn. In 1991, 20 stations were held for a total of 458 min, and in 1994, 44 stations were held for a total of $512 \mathrm{~min}$. Where appropriate, recordings were made on a Uher $4000 \mathrm{~S}$ recorder.

Between 3 December 1996 and 2 January 1997, the whale sighting vessels 'Shonan Maru' and 'Shonan Maru \# $2^{\prime}$ searched the area between $25^{\circ}$ and $36^{\circ} \mathrm{S}$, $19^{\circ}$ and $52^{\circ} \mathrm{E}$ south of Madagascar as part of the IWC/SOWER blue whale survey (Fig. 2). Systematic watches for cetaceans were held between 06:00 and 18:00 $\mathrm{h}$ every day, weather permitting, with 2 observers in a masthead lookout and at least 2 more on the front bridge, all searching with $7 \times 50$ binoculars. Distances to sightings were estimated by the person making the sighting and angles from the trackline read off an angleboard or estimated from markings on the front dodger of the bridge. Sightings made while the vessels were on full searching effort were recorded as primary, while those made at other times (during confirmation, chasing, etc.) were recorded as secondary.

Humpback whales produce long and complex songs during their breeding season. Most singers seem to be male, and (following Tyack 1981) it has been assumed that singing humpbacks are probably communicating inter alia their readiness to mate with females and to engage in agonistic behaviour with other whales. Acoustic detection of singing humpback whales is therefore taken as an indication of potential reproductive activity. 
Table 1 Details of acoustic watches at Cape Vidal, South Africa, 1989 and 1990

\begin{tabular}{|c|c|c|c|c|}
\hline Date & Time started $(\mathrm{h})$ & Duration (min) & $\begin{array}{c}\text { Whales present } \\
\text { (comma separates groups) }\end{array}$ & Singers present \\
\hline \multicolumn{5}{|c|}{ Northbound migration } \\
\hline 1 Jul 1989 & $-12: 00$ & 24.58 & None & No \\
\hline 2 Jul 1989 & 11:00 & 37.43 & None & No \\
\hline 4 Jul 1990 & $15: 51$ & 22.0 & 4-6 humpback & No \\
\hline 5 Jul 1989 & $\begin{array}{l}\sim 11: 15 \\
>12: 00\end{array}$ & $\begin{array}{l}6.88 \\
39.4\end{array}$ & $\begin{array}{l}5 \text { humpback } \\
\text { None }\end{array}$ & $\begin{array}{l}\text { No } \\
\text { No }\end{array}$ \\
\hline \multirow[t]{2}{*}{6 Jul 1990} & $14: 58$ & 10.0 & 3 humpback & No \\
\hline & $16: 22$ & 10.0 & 1 humpback & No \\
\hline 7 Ju] 1989 & 1500 & 25.82 & 3 or 4 humpback & Yes \\
\hline 12 Jul 1989 & 09:07 & 9.58 & None & No \\
\hline 13 Jul 1989 & $10: 30$ & 26.35 & 2 or 3,3 humpback & No \\
\hline 14. Jul 1989 & $-13: 15$ & 9.42 & 2 humpback & No \\
\hline 15 Jul 1989 & $11: 30$ & 12.2 & 2 humpback & No \\
\hline \multirow{2}{*}{16 Jul 1989} & 10:00 & 10.07 & None & No \\
\hline & $\sim 11: 00$ & 7.22 & None & No \\
\hline \multirow[t]{4}{*}{17 Jul 1989} & $12: 52$ & 13.78 & 4 humpback & Yes \\
\hline & $\sim 13: 30$ & 4.73 & 4 humpback & Yes \\
\hline & $15: 50$ & 4.13 & 3 humpback & No \\
\hline & $16: 00$ & 6.33 & None & No \\
\hline \multirow[t]{2}{*}{18 Jul 1990} & $10: 05$ & 10.0 & 2 humpback & No \\
\hline & $13: 55$ & 27.0 & 2 humpback & Yes \\
\hline \multirow{2}{*}{$20 \mathrm{Jul} 1990$} & $12: 00$ & 25.0 & 2 humpback & No \\
\hline & $14: 05$ & 15.0 & 4 humpback & No \\
\hline 21 Jul 1989 & $14: 00$ & 5.6 & 2 or 3 humpback & No \\
\hline \multirow[t]{8}{*}{21 Jul 1990} & $09: 52$ & 19.0 & 1 humpback & No \\
\hline & $1.0: 17$ & 8.0 & None & No \\
\hline & $10: 33$ & 47.0 & None & No \\
\hline & $11: 24$ & 56.0 & None & No \\
\hline & $12: 32$ & 13.0 & 1 humpback & No \\
\hline & $12: 49$ & 80.0 & 1 humpback & No \\
\hline & $14: 26$ & 55.0 & None & No \\
\hline & $15: 51$ & 21.0 & 1 humpback? & No \\
\hline 22 Jul 1989 & $09: 54$ & 14.47 & 2 humpback & No \\
\hline \multirow[t]{2}{*}{22 Jul 1990} & $11: 03$ & 12.0 & 3 humpback & Yes \\
\hline & $12: 40$ & 10.0 & 1 humpback & No \\
\hline \multicolumn{5}{|c|}{ Southbound migration } \\
\hline \multirow[t]{2}{*}{16 Sep 1990} & $10: 00$ & 18.0 & 2 right whales & Yes $^{d}$ \\
\hline & $10: 31$ & 13.0 & 2 nght whales & Yes $^{a}$ \\
\hline \multirow[t]{5}{*}{22 Sep 1990} & $09: 44$ & 15.0 & 2, 2 humpback & No \\
\hline & $10: 36$ & 14.0 & 2 humpback & No \\
\hline & $11: 30$ & 10.0 & 2 humpback & No \\
\hline & $15: 50$ & 30.0 & 5 humpback & No \\
\hline & $16: 57$ & 12.0 & 5 humpback & No \\
\hline \multirow[t]{5}{*}{24 Sep 1990} & $07: 58$ & 32.0 & 1 unidentified & No \\
\hline & $09: 39$ & 30.0 & None & No \\
\hline & $10: 48$ & 32.0 & None & No \\
\hline & $12: 05$ & 43.0 & None & No \\
\hline & $13: 01$ & 36.0 & None & No \\
\hline \multirow[t]{3}{*}{25 Sep 1990} & $08: 17$ & 31.0 & 2 humpback & No \\
\hline & $10: 42$ & 31.0 & None & No \\
\hline & $13: 44$ & 30.0 & 3,1 humpback & Yes \\
\hline 26 Sep 1990 & 09.30 & 25.0 & 2 humpback & No \\
\hline 28 Sep 1990 & $12: 17$ & 21.0 & 1 humpback & Yes \\
\hline 29 Sep 1990 & $09: 45$ & 60.0 & None & No \\
\hline
\end{tabular}


Table 1 (continued)

\begin{tabular}{|c|c|c|c|c|}
\hline Date & Time started (h) & Duration (min) & Whales present & Singers present \\
\hline \multirow{4}{*}{30 Sep 1990} & $09: 35$ & 43.0 & 1 humpback & Yes \\
\hline & $10: 45$ & 31.0 & None & Yes \\
\hline & 13:01 & 19.0 & 1 right whale & Yes \\
\hline & $13: 26$ & 16.0 & 1 right whale & Yes \\
\hline 1 Oct 1990 & $12: 20$ & 30.0 & 4 humpback & Yes \\
\hline \multirow[t]{6}{*}{4 Oct 1990} & 09:09 & 36.0 & 5 humpback & Yes \\
\hline & $10: 15$ & 25.0 & 5 humpback & Yes \\
\hline & $11: 12$ & 30.0 & 5 humpback & Yes \\
\hline & $11: 49$ & 14.0 & 5 humpback & Yes \\
\hline & $12: 22$ & 29.0 & 5 humpback & Yes \\
\hline & $15: 27$ & 43.0 & None & Yes \\
\hline \multirow[t]{5}{*}{5 Oct 1990} & $08: 15$ & 30.0 & None & Yes \\
\hline & $09: 25$ & 35.0 & 2 humpback & Yes \\
\hline & $12: 02$ & 6.0 & None & No \\
\hline & $13: 05$ & 82.0 & None & Yes \\
\hline & $15: 10$ & 23.0 & None & No \\
\hline
\end{tabular}

\section{RESULTS}

\section{East coast of South Africa}

Knysna Heads $\left(34^{\circ} 05^{\prime} \mathrm{S}, 23^{\circ} 04^{\prime} \mathrm{E}\right)$

Between 1903 and 1906 (which predated the onset of commercial whaling on the population), as many as 250 to 450 humpback whales are estimated to have migrated past the Heads annually within sight of land. Given the direction of movement recorded (eastward from April to August/September and westward from August/September to December), these whales must have been headed for a wintering ground up the east coast (Best \& Ross 1996).

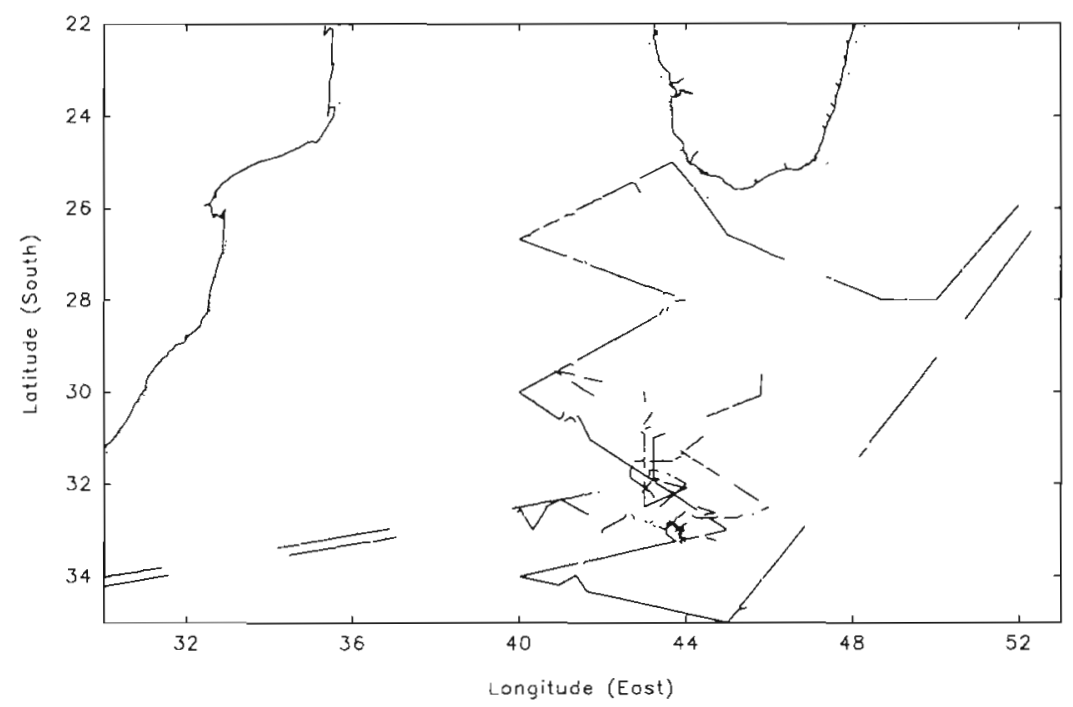

Fig. 2. Southwest Indian Ocean, showing the on-effort cruise track of the 'Shonan Maru' and 'Shonan Maru \# 2', 3 December 1996 to 2 January 1997

Durban whaling ground $(150 \mathrm{n}$ miles seaward of $29^{\circ} 54^{\prime} \mathrm{S}, 31^{\circ} 03^{\prime} \mathrm{E}$ )

Seasonality of catch. Olsen (1914) lists catch data by $10 \mathrm{~d}$ period for the South African Whaling Company's station at Durban for the years 1910 to 1912 . In 1912, catches were affected by a strike during the peak of the northern migration and by a lack of whales during the spring migration-the latter may have represented the beginnings of stock depletion, for from 1913 onwards, humpback whales no longer formed the majority of the Durban catch (Best 1994).
In a multispecies fishery for which effort data by species are not available, trends in abundance are difficult to evaluate. For these reasons only the data for 1910 and 1911 are presented here (Fig. 3a). The 2 plots are almost identical, with peaks in catchper-boat in the last $10 \mathrm{~d}$ of July and in mid to late September. These presumably represent the timing of peak northward and southward migrations respectively.

Aerial spotting data. Between 1972 and 1975, the spotter aircraft attached to the Union Whaling Co.'s station at Durban made 21 sightings of 38 humpback 

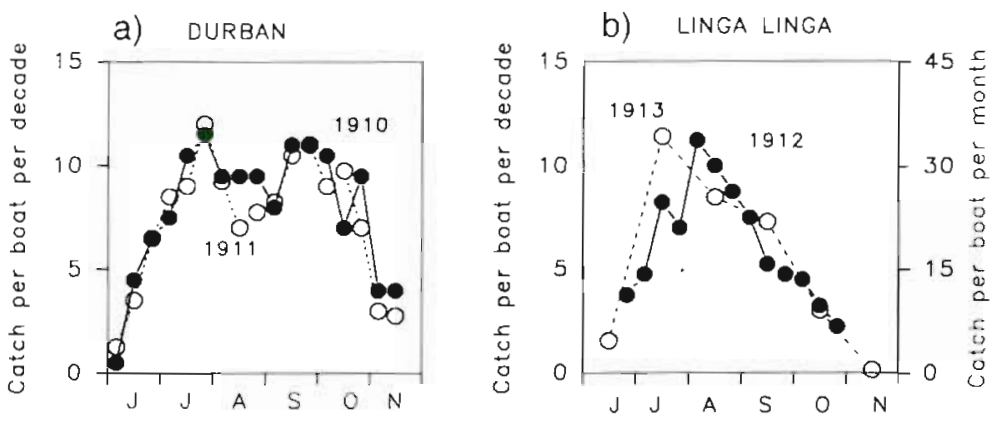

C) CAPE VIDAL
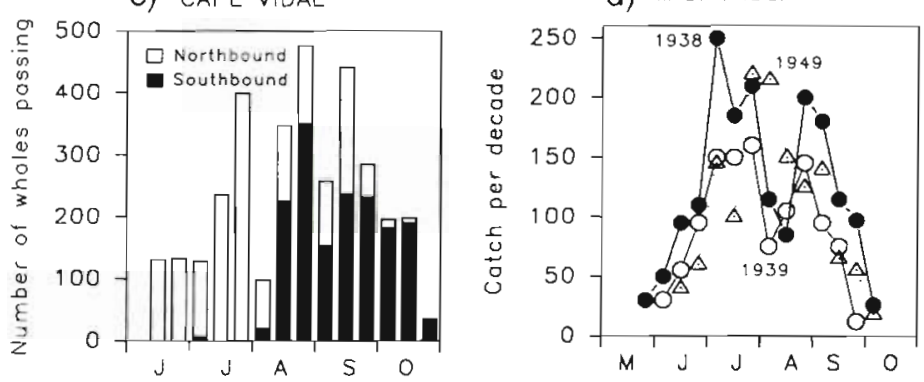

Fig. 3. Seasonal incidence of catches or sightings of humpback whales at different localities in the southwest Indian Ocean

whales. These are too few to give any indication of seasonality, although all but 2 were recorded in the months of June to September. Sightings were made from the nearshore region to as much as $100 \mathrm{n}$ miles offshore. Associated sighting effort is available (as numbers of miles flown) by water depth but not by distance offshore (Findlay 1989). The density of whales calculated by depth interval is bimodal, with a major

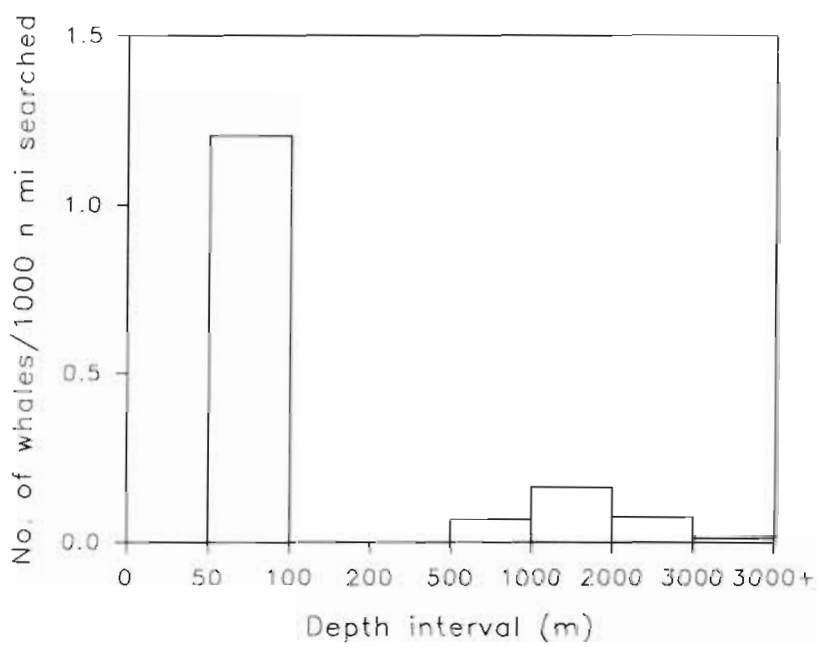

Fig. 4. Distribution of humpback whales with depth in the Durban whaling grounds, based on sightings from the spotter aircraft, $1972-1975$ peak at 50 to $100 \mathrm{~m}$ and a secondary peak at 1000 to $2000 \mathrm{~m}$ depth (Fig. 4). On the Durban whaling grounds the $1000 \mathrm{~m}$ isobath lies between 10 and $50 \mathrm{n}$ miles offshore, so that although the main migration stream may be close inshore, a second, smaller stream must pass some distance offshore.

\section{Cape Vidal $\left(28^{\circ} 07^{\prime} \mathrm{S}, 32^{\circ} 33^{\prime} \mathrm{E}\right)$}

Seasonality of sightings. Shore-based surveys at Cape Vidal were undertaken annually from 1988 to 1991, but only in 1990 did the survey have comprehensive seasonal coverage, from 2 June to 28 October. The numbers of whales estimated to have passed Cape Vidal during each 10 d period between 1 June and 31 October 1990 show an overall bimodality, with peaks in late July and late August (Fig. 3b). The first peak was composed almost entirely of northward-moving whales and the second peak mainly of southward-moving whales.

Distribution of sightings. The width of the migratory path off Cape Vidal was not determined directly by onshore-offshore transects and can only be inferred from the distribution of sightings from the shore as determined from shore-based towers. This procedure has a number of disadvantages, in particular the difficulty of distinguishing between the natural decline in sightability of groups with distance from the shore, and a possible real onshore-offshore gradient in the abundance of migrating humpback whales. Humpbacks were seen up to $19 \mathrm{~km}$ from the shore, but the modal number occurred (in all years except 1988) at 2 to $3 \mathrm{~km}$ in northward-moving animals; the southward migration in 1990 was significantly further offshore than any of the northward migrations, the mode occurring at 3 to $4 \mathrm{~km}$ (Findlay \& Best 1996a). This difference in offshore distribution between the 2 migrations was explained by northward-moving animals being funnelled inshore by the topography of the coastline, and in doing so possibly avoiding the southward-flowing Agulhas Current found further offshore (Findlay \& Best 1996a)

Estimates of the number of whales on the northward and southward migrations in 1990 were 1711 and 1647 respectively (Findlay \& Best 1996b).

Acoustic data. At the 34 acoustic stations held at Cape Vidal on 18 different days in July for during the northern migration), singing humpbacks were detected on only 5 occasions, on 4 different days 
(Table 1). At the 34 stations held on 11 different days in September/October for during the southern migration), however, singers were detected on 18 occasions, on 7 different days. Because there was a tendency for repeat stations to be held on days when singers were recorded, a better test of the frequency of occurrence of singers is the proportion of days on which singers were heard. During September/October there was a higher daily incidence of singers than in July (Fisher's exact test, 2 -tailed, $\mathrm{p}<0.001$ ).

\section{Mozambique}

Seasonality of catch. Olsen (1914) and Lea (1919) present data on seasonal catch rates for humpback whales landed at Linga Linga $\left(23^{\circ} 47^{\prime} \mathrm{S}, 35^{\circ} 32^{\prime} \mathrm{E}\right)$ in the 1912 and 1913 seasons respectively, when the catch was almost entirely humpback whales. Both data sets indicate a unimodal seasonality, although the timing of the peak is slightly different-the first $10 \mathrm{~d}$ period of August in 1912 and in July in 1913 (Fig. 3c). As first suggested by Harmer (1931), such unimodality may indicate that the northward migration does not proceed much further than this latitude.

Distribution of sightings. During August and September 1991, humpback whales were found throughout the coastal waters of Mozambique between the latitudes of $18^{\circ}$ and $26^{\circ} \mathrm{S}$, and although the northern sector (north of $21^{\circ} \mathrm{S}$ ) contained a higher proportion of calves than the southern, there was no other evidence that the northernmost limit of the wintering grounds had been reached (Findlay et al. 1994). Townsend's (1935) charts indicate nineteenth-century catches clustered around the town of Mozambique at $12^{\circ} \mathrm{S}$. There was also no overwhelming evidence that the distribution of whales was influenced by water depth, the densities of humpbacks in water 0 to 36.6 and 36.6 to $183 \mathrm{~m}$ deep being not significantly different (Findlay et al. 1994). Some longshore areas of the coast had higher densities than others, particularly between $33^{\circ}$ and $35^{\circ} 30^{\prime} \mathrm{E}$, where the coast ran more east-west than in the remainder of the survey area, and consequently the warm, southward-flowing Mozambique Current passed further offshore. As a result, there were higher densities of humpbacks in cooler water than expected. The numbers of humpback whales present in the area surveyed was estimated at 1954 (CV 0.38).

Acoustic data. On the coast of Mozambique in August/September 1991, singing humpback whales were detected at 14 out of 20 acoustic stations, extending from $18^{\circ} 23^{\prime} \mathrm{S}$ to $25^{\circ} \mathrm{S}$ (Fig. 5). The hydrophone received some damage during recovery at the first station, and although it was subsequently repaired, it did not function at full efficiency for the rest of the cruise

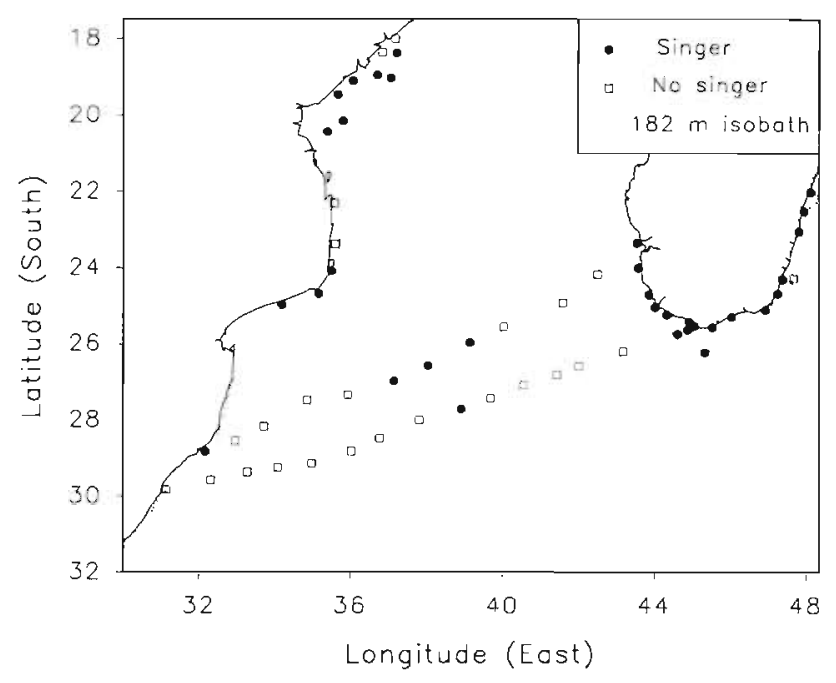

Fig. 5. Locations of acoustic stations held for singing humpback whales in August and September, 1991 and 1994, in the southwest Indian Ocean

(and its use was abandoned after Stn 20). The lack of singers at 2 stations could be attributed to hydrophone damage (Stn 1) and shielding by land when anchored inside Paradise Island, Bazaruto Archipelago (Stn 20). The remaining 4 stations with no singers were Stns 8 , 9, 10 and 12, between 23 and 29 August: on 31 August new headphones were tried out and the difference in reception was very noticeable. It is therefore possible that the scarcity of singers between 23 and 29 August was at least partly due to poor reception. With these caveats it appears that reproductively active (= singing) humpback whales were distributed throughout the coastal waters of southern and central Mozambique in August/September

Excluding Stns 1 and 20, the incidence of singers at acoustic stations on the coast of Mozambique in August/September (14/18) was higher than the daily incidence of singers recorded off Cape Vidal in July $\left(\chi^{2}\right.$ $=9.0, p<0.005$ ), but not significantly different from the daily incidence of singers off Cape Vidal in September/October (Fisher's exact test, $\mathrm{p}>0.05$ ).

\section{Coast of Madagascar}

Seasonality of catch. There have been 2 main episodes of twentieth-century whaling in the coastal waters of Madagascar, 1937 to 1939 and 1949 to 1950 ; humpback whales formed at least $95 \%$ of the catch in both episodes (Best et al. 1996). Bermond (1950) illustrated cumulative catches of humpback whales by $10 \mathrm{~d}$ period for the seasons 1938, 1939 and 1949. These have been separated by $10 \mathrm{~d}$ period in Fig. 3d. In 1938 and 1939 the trend was similar, a bimodality with 
peaks in July and in late August/early September. In 1949 the bimodality was not so evident, although in a more detailed analysis of the same data Angot (1951) illustrated a bimodality with peaks in late July and early September. Angot attributed the second mode in catches to a resumption of whaling on the south coast after a 2 wk period during which the expedition had been on the east coast; he reasoned catches were temporarily higher in early September because the whales on the south coast had had time to regroup in the interim. No data are available on the movements of the expeditions in 1938 and 1939 to see whether a similar explanation might account for the bimodality in those seasons, but it seems unlikely that operations would have been conducted in an identical manner in all 3 seasons, especially as entirely different expeditions were involved in 1938/1939 and in 1949.

Bermond (1950) also illustrated the distribution of catches of humpback whales in 5 zones round Madagascar in 1938,1939 and 1949. Catches east of $44^{\circ} 10^{\prime} \mathrm{E}$ and south of $24^{\circ} 30^{\prime} \mathrm{S}$ (or at the southern and southeastern tip of the country) predominated in all 4 seasons: $90 \%$ in $1938,78.1 \%$ in 1939 and $78.8 \%$ in 1949 . The bimodality of catches by $10 \mathrm{~d}$ period in these seasons may therefore indicate that the migration proceeded some distance north of $24^{\circ} 30^{\prime} \mathrm{S}$. Nineteenthcentury catches depicted by Townsend (1935) indicate catches concentrated not only in the southwest (near Tulear) but also in the northeast (around Baie $\mathrm{d}^{\prime}$ Antongil, at about $15^{\circ} 30^{\prime} \mathrm{S}$ ) and scattered along the west coast around $20^{\circ} \mathrm{S}$. Recently Rosenbaum et al. (1997) have also recorded the presence of a humpback whale wintering ground in Baie d'Antongil. A northward extension of the main migration beyond $24^{\circ} 30^{\prime} \mathrm{S}$ is therefore quite likely, so that the bimodality in catch rates would then reflect general northward and southward movements through the coastal waters of southern Madagascar

Distribution of sightings. During the survey of the coastal waters of Madagascar south of $22^{\circ} \mathrm{S}$ in August 1994, humpback whales were found throughout the area surveyed (Best et al. 1996). Although sighting rates were lower on the east than the south coast, there was no evidence that the northern limit of the winter distribution had been reached: the proportion of calves encountered on the east coast was no higher than that encountered on the south coast, for example. Sea surface temperatures recorded at $07: 00$ h each day were 22 to $23^{\circ} \mathrm{C}$ west of $44^{\circ} 15^{\prime} \mathrm{E}$ (the west coast), 21 to $22^{\circ} \mathrm{C}$ between $44^{\circ} 15^{\prime}$ and $47^{\circ} 15^{\prime} \mathrm{E}$ (the south coast) and 23 to $24.5^{\circ} \mathrm{C}$ east of $47^{\circ} 15^{\prime} \mathrm{E}$ (the east coast). Given the lower densities recorded on the east coast, this situation seems to parallel that in Mozambique, in that humpback whales tended to favour areas where the coast ran in an east-west rather than north-south direction, with a wider continental shelf and in cooler waters shorewards of a southward-flowing warm current. The bathymetry of the coastal waters of Madagascar is too poorly documented to permit testing for differences in distribution with depth. The number of humpback whales in the area surveyed was estimated as 2532 (CV 0.27).

Acoustic data. On the coast of Madagascar in August/September 1994, singing whales were detected at 18 out of 19 stations (Fig. 5). The exception was a station at $24^{\circ} 16.5^{\prime} \mathrm{S}$ on the east coast, $17 \mathrm{n}$ miles offshore and in a water depth exceeding $500 \mathrm{~m}$. Three hours later, an acoustic station inshore in a water depth of about $46 \mathrm{~m}$ revealed the presence of many singers. The straight-line distance between the 2 stations was $18 \mathrm{n}$ miles, giving some indication of the maximum distance at which singers might be heard. The acoustic data indicate that reproductively active ( $=$ singing) humpback whales were widely distributed over the continental shelf of southern Madagascar in August/ September.

\section{Southwest Indian Ocean}

Distribution of sightings. During the 'Pieter Molenaar' cruise in the southwest Indian Ocean in the summer of $1973 / 74$, only 2 sightings of humpback whales were made (Fig. 1). On 26 November a cow and calf were seen at $33^{\circ} 12^{\prime} \mathrm{S}, 38^{\circ} 00^{\prime} \mathrm{E}$, and on 4 January 2 adults were encountered at $35^{\circ} 30^{\prime} \mathrm{S}, 42^{\circ} 47^{\prime} \mathrm{E}$ (Gambell et al. 1975). The scarcity of sightings is not surprising, given the lateness of the season.

When the 'Vityaz' visited Walters Shoal in December 1988; 'The humpbacks ... were most impressive... We were in the vicinity from $8-25$ th December. While we saw groups of 2-3 humpbacks widely in the area, the highest densities (ca $1 / \mathrm{km}^{2}$ ) occurred in this shallow region [about $3 \mathrm{n}$ miles in diameter around $33^{\circ} 13^{\prime} \mathrm{S}$, $43^{\circ} 54^{\prime} \mathrm{E}$, where depths reached only $15-18 \mathrm{~m}$ ]. There seemed to be an increasing number of cows and calves over the period we were there and we were treated to the full range of humpback antics at the surfacebroaching (frequently), flipper and tail waving. The currents were exceptionally strong in the shallow zone, with standing waves visible at times, and midwater trawling produced large numbers of Systellapsis by day at $600 \mathrm{~m}$ in $850 \mathrm{~m}$ soundings around the edge of this zone. Over the top of these shallows there was a fair density of Trachurus also. Both of these, presumably, could have provided the incentive to keep whales in the area. The humpbacks took little notice of the ship and I should think literally hundreds of photos were taken' (N. Merrett pers, comm. 24 October 1989). 


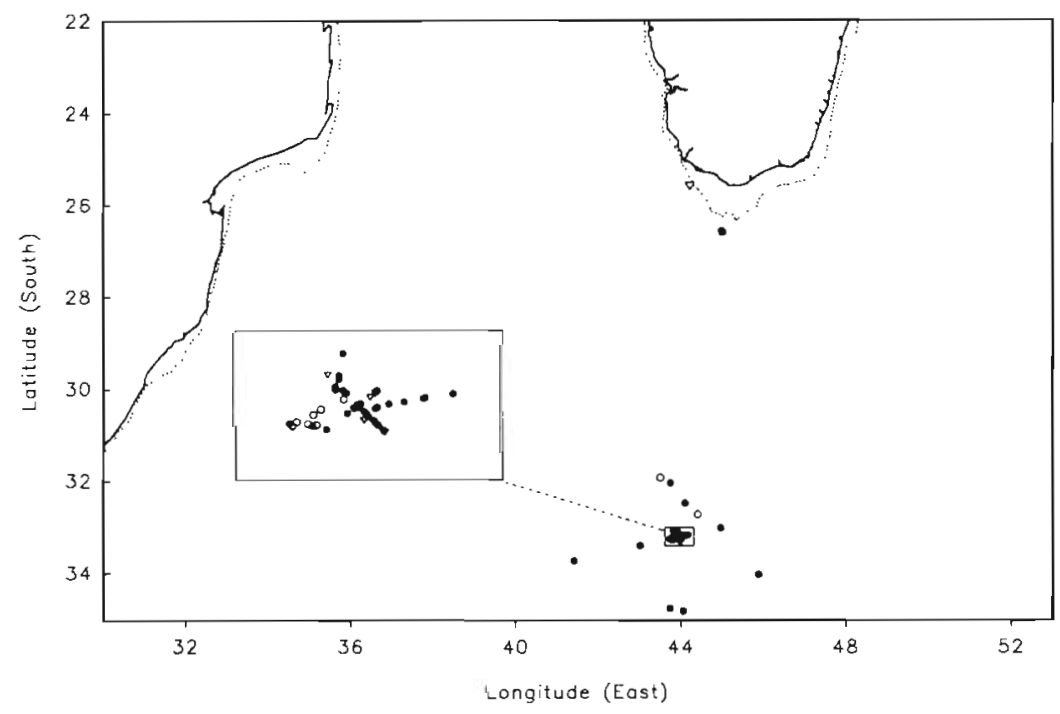

Fig. 6. Distribution of humpback whale sightings on the Madagascar Ridge, December 1996. ( $\bullet$ Primary sightings; (0) secondary sightings; ( $\nabla$ ) like-humpback sightings. Inset: Walters Shoal area recorded humpback whales only along the southern coast of Madagascar 18 sightings of 27 whales on 20 October and 7 sightings of 10 whales on 28 October) and on the South African coast (1 sighting of a single whale on 26 October)

Reeves et al. (1991) listed 6 unpublished records of humpback whales in the western Indian Ocean. Four of these were from the Aldabra Islands or their vicinity (at about $9^{\circ} \mathrm{S}, 46^{\circ} \mathrm{E}$ ) and 2 from the Comores Islands (about $12^{\circ} 30^{\prime} \mathrm{S}, 44^{\circ} \mathrm{E}$ ). All were from the period September/October, and 1 involved a cow-calf pair. To these can be added reports of a minimum of 11 individuals seen in $12 \mathrm{~d}$ at sea off Mayotte in the Comores, 5 of which were cow-calf pairs (Seitre pers. comm. 13 October 1995). These island groups lie almost halfway between the

During December/January 1996/97, 54 sightings of 113 humpback whales were made by the 'Shonan Maru' and 'Shonan Maru \# 2' combined on their search of the Madagascar Ridge (Fig. 6). Of these, 41 sightings of 85 whales were made in the vicinity of Walters Shoal during visits by the 'Shonan Maru' on 11 and 12 December and by the 'Shonan Maru \# 2' on 27 December (see insert in Fig. 6). If the number of primary sightings per $10 \mathrm{~h}$ searched is analysed for each degree of longitude, there is a major peak in the incidence of humpback whales at $43^{\circ}$ to $44^{\circ} 59^{\prime} \mathrm{E}$, and a minor peak at $20^{\circ}$ to $20^{\circ} 59^{\prime} \mathrm{E}$ (Table 2). Most of the major peak is due to the influence of Walters Shoal: if the sightings and effort for this area are excluded, this peak is much reduced. Although relatively low levels of searching effort were made outside the sector $40^{\circ}$ to $45^{\circ} \mathrm{E}$, humpback whales were only seen between $20^{\circ}$ and $20^{\circ} 59^{\circ} \mathrm{E}$ and between $41^{\circ}$ and $45^{\circ} 59^{\prime} \mathrm{E}$.

Despite sightings of sperm whales (schools of 11, 12 and 12 animals), beaked whales (3), bottlenose dolphins (25), and 1 blue whale during the $3 \mathrm{~d}$ (28 to 30 January 1974) that the 'Pieter Molenaar' was at Walters Shoal, no humpback whales were seen (Gambell et al. 1975).

In transits from Mauritius $\left(20^{\circ} 15^{\prime} \mathrm{S}\right.$, $57^{\circ} 30^{\prime} \mathrm{E}$ ) to Durban and back again in October/November 1991, Corbett (1994)
Table 2. Searching effort and number of humpback whale sightings from 'Shonan Maru' and 'Shonan Maru \# 2' by degree of longitude, December' January 1996/97 (values in parentheses exclude Walters Shoal area)

\begin{tabular}{|lccc|}
\hline $\begin{array}{l}\text { Longitude } \\
\text { (E) }\end{array}$ & $\begin{array}{c}\text { Effort } \\
\text { (h searching) }\end{array}$ & $\begin{array}{c}\text { No. of primary } \\
\text { sightings }\end{array}$ & $\begin{array}{c}\text { Density of sightings } \\
\text { (sightings/10 h) }\end{array}$ \\
\hline $19^{\circ}$ to $19^{\circ} 59^{\prime}$ & 0.38 & 0 & 0 \\
$20^{\circ}$ to $20^{\circ} 59^{\prime}$ & 6.9 & 1 & 1.45 \\
$21^{\circ}$ to $21^{\circ} 59^{\prime}$ & 8.53 & 0 & 0 \\
$22^{\circ}$ to $22^{\circ} 59^{\prime}$ & 0.75 & 0 & 0 \\
$29^{\circ}$ to $29^{\circ} 59^{\prime}$ & 3.98 & 0 & 0 \\
$30^{\circ}$ to $30^{\circ} 59^{\prime}$ & 8.75 & 0 & 0 \\
$31^{\circ}$ to $31^{\circ} 59^{\prime}$ & 4.08 & 0 & 0 \\
$34^{\circ}$ to $34^{\circ} 59^{\prime}$ & 5.42 & 0 & 0 \\
$35^{\circ}$ to $35^{\circ} 59^{\prime}$ & 8.53 & 0 & 0 \\
$36^{\circ}$ to $36^{\circ} 59^{\prime}$ & 7.88 & 0 & 0 \\
$37^{\circ}$ to $37^{\circ} 59^{\prime}$ & 0.24 & 0 & 0 \\
$39^{\circ}$ to $39^{\circ} 59^{\prime}$ & 0.32 & 0 & 0 \\
$40^{\circ}$ to $40^{\circ} 59^{\prime}$ & 40.62 & 0 & 0 \\
$41^{\circ}$ to $41^{\circ} 59^{\prime}$ & 40.94 & 1 & 0 \\
$42^{\circ}$ to $42^{\circ} 59^{\prime}$ & 40.33 & 0 & 0.60 \\
$43^{\circ}$ to $43^{\circ} 59^{\prime}$ & 69.53 & 32 & 0.53 ) \\
$44^{\circ}$ to $44^{\circ} 59^{\prime}$ & $(56.26)$ & $13)$ & 0 \\
$45^{\circ}$ to $45^{\circ} 59^{\prime}$ & 31.44 & 9 & 0.86 \\
$46^{\circ}$ to $46^{\circ} 59^{\prime}$ & 23.19 & $(4)$ & $0.43)$ \\
$47^{\circ}$ to $47^{\circ} 59^{\prime}$ & 2.85 & 1 & 0 \\
$48^{\circ}$ to $48^{\circ} 59^{\prime}$ & 10.45 & 0 & 0 \\
$49^{\circ}$ to $49^{\circ} 59^{\prime}$ & 11.69 & 0 & 0 \\
$50^{\circ}$ to $50^{\circ} 59^{\prime}$ & 9.18 & 0 & 0 \\
$51^{\circ}$ to $51^{\circ} 59^{\prime}$ & 14.39 & 0 & 0 \\
$52^{\circ}$ to $52^{\circ} 59^{\prime}$ & 2.12 & 0 & 0 \\
\hline
\end{tabular}




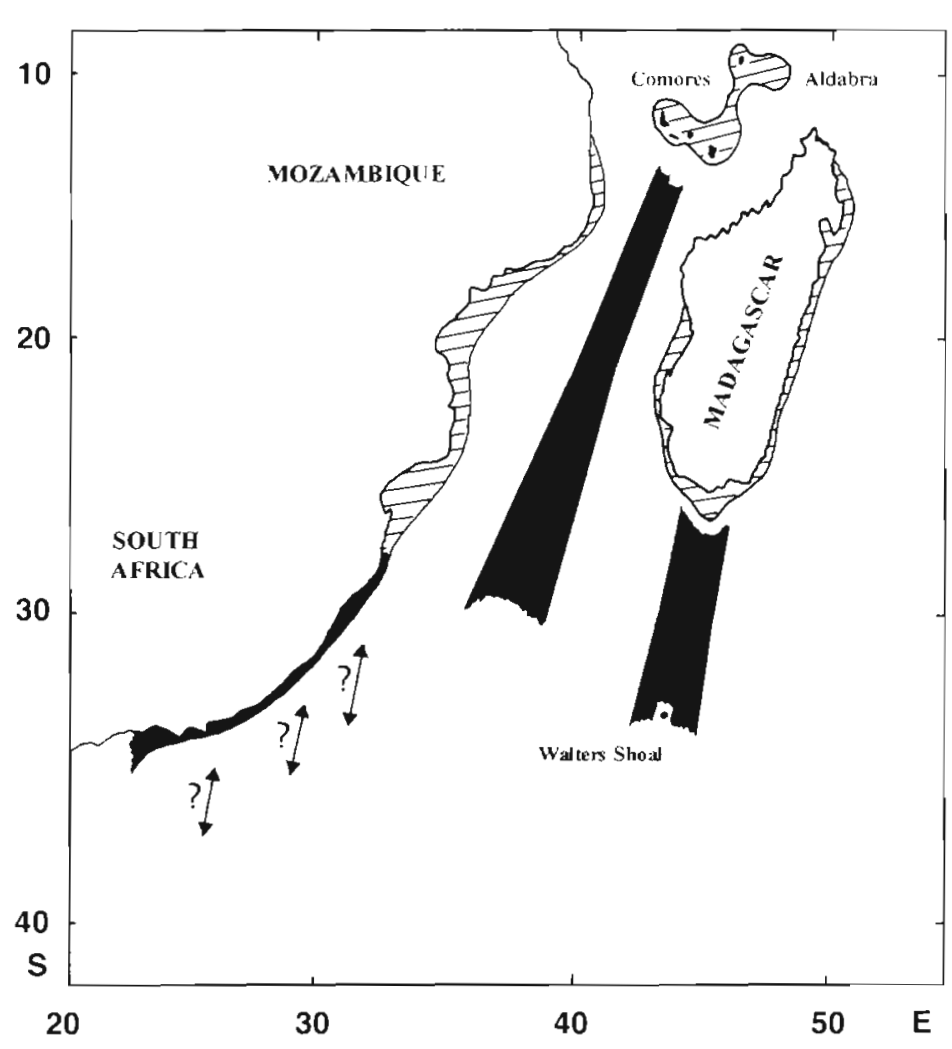

Fig. 7 Diagram of proposed migratory routes for humpback whales in the southwest Indian Ocean (hatched areas indicate possible extent of breeding grounds). The widths of the proposed routes are not necessarily correlated with the numbers of animals using them

Acoustic data. During transits across the Mozambique Channel from Richards Bay to Tulear (30 July to 3 August 1994) and from Cap Sainte-Marie to Durban (2 to 6 September 1994), a total of 23 acoustic stations were held beyond the continental shelves of South Africa or Madagascar (Fig. 5). Singing humpback whales were detected at 4 stations, 3 on the earlier and 1 on the later transit. All 4 stations were located between $37^{\circ}$ and $39^{\circ} \mathrm{E}$, roughly in the middle of the Mozambique Channel, and in water depths exceeding $3000 \mathrm{~m}$. In addition, acoustic stations were held on the coast of South Africa on 29 July and on 6 September 1994: singing humpbacks were heard at the first but not the second. However the latter station was held in the roadstead of Durban harbour, with several large ships in the vicinity from which ship noise was emanating.

\section{DISCUSSION}

From the evidence in this paper it is proposed that there are 3 principal migratory streams for humpback whales in the southwest Indian Ocean, one on the east coast of southern Africa, one along the Madagascar
Ridge, and one in the central Mozambique Channel. These are shown diagrammatically in Fig. 7.

\section{(1) East Africa}

On its northward migration, this stream strikes the coast at least as far west as $23^{\circ} \mathrm{E}$, and as early as April. The timing of the peak(s) in migration at Knysna was not recorded, but the reversal of movement occurred in August or September. The bimodality of catches at Durban and of sightings at Cape Vidal suggests that this migration continues to the north of both localities, and the direction of movement recorded at Cape Vidal supports this contention. The first peak at Durban is in the last $10 \mathrm{~d}$ of July, as it is at Cape Vidal. Off Mozambique the distribution of catches was unimodal; using the data for 1912 because it is more detailed, the peak occurred in the first $10 \mathrm{~d}$ of August. The peak in southward-moving humpbacks occurred at Cape Vidal in the last $10 \mathrm{~d}$ of August, and the second peak in catching at Durban was in middle and late September. The last westward-moving humpbacks at Knysna were recorded in December. The sighting of a cow and calf from the 'Shonan Maru \# 2' on 2 January 1997 at $35^{\circ} 22.04^{\prime}$ S, $20^{\circ} 10.85^{\prime} \mathrm{E}$, or about $35 \mathrm{n}$ miles off the southern tip of Africa, might suggest that for some individuals of the East African population the southern migration extends as far west as $20^{\circ} \mathrm{E}$. Alternatively, these could represent animals from the West African breeding population.

The width of the migration at Knysna is unknown. Comparing the (pre-exploitation) estimate of 'several hundred' animals seen from the shore in 1903-1906 (Best \& Ross 1996) with the figures (for a still depleted stock) of 1600 to 1700 passing Cape Vidal in 1990 (Findlay \& Best 1996b) seems to suggest that a substantial proportion of the animals either passed offshore of, or was missed by, the observers at Knysna. At Durban the aerial observations indicate 2 streams of migrating animals, one inshore and the other offshore. It is not clear whether the latter represents animals that migrate close to the coast further north, or whether they are the inshore edge of a separate stream migrating parallel to the coast. At Cape Vidal the peak in offshore distribution (at 2 to $3 \mathrm{~km}$ for northern and 3 to $4 \mathrm{~km}$ for southern migrations) is close enough to the coast to suggest that the subsequent fall off in abundance with distance offshore is at least partly a real effect. The similarity in the estimates of abundance for whales passing within sight 
of Cape Vidal in 1990 (1711 going north and 1647 going south) and for whales surveyed by yacht on the continental shelf of southern central Mozambique in 1991 (1954, CV 0.38) could be taken as indicating that essentially the whole stream of humpbacks passed within view of the shore at Cape Vidal. However the 1991 survey did not seem to cover the entire distribution of humpbacks in Mozambique coastal waters, and so may be an underestimate.

The winter destination of this migratory stream is almost certainly the coastal waters of Mozambique. The seasonality of catches in this locality (at Linga Linga) is characterised by a single peak and by a narrower seasonal range than at either Cape Vidal or Durban, suggesting that the 2 migration waves essentially converge in southern/central Mozambique. The relative infrequency of singing humpbacks in July at Cape Vidal (compared to the coastal waters of Mozambique in August/September) also implies that most mature males do not commence reproductive activity (= singing) until north of Cape Vidal, indicating that the breeding ground is to the north of Cape Vidal.

The small difference (ca $5 \%$ ) between the estimates of abundance for northern and southern migrations at Cape Vidal in 1990 suggests that a similar proportion of the population uses the coastal route on both migrations. Unlike the northern migration, where there is little difference in the timing of the peaks at Durban. Cape Vidal and at Linga Linga (late July to early August), the southern migration is characterised by significantly later peaks at each locality: early August at Linga Linga, late August at Cape Vidal and middle to late September at Durban. The southern migration may thus be more protracted and slower than the northern

\section{(2) Madagascar Ridge}

The bimodal seasonality of catches in southern Madagascar is similar to that described for Cape Vidal and Durban, from which it might be inferred that the general wave of migration continues some distance to the north. Unlike Cape Vidal in July, however, the high incidence of singing humpback whales at acoustic stations in southern Madagascar in August indicates that males are reproductively active in the area. It is not clear whether this difference is a reflection of the later timing or the lower latitude of the acoustic surveys off Madagascar.

The peak catches in southern Madagascar (July and late August/early September) were also contemporary with those at Durban. This suggests that the movements into East African and Madagascan waters are not sequential but separate. Furthermore, the com- bined size of the humpback whale populations in southern/central Mozambique in August/September 1991 and in southern Madagascar in August 1994 (some 4500 individuals) is far greater than estimates of the East African migratory stream in 1990 (1700 to 1900 individuals). Even allowing for some population increase since 1990, it seems that humpback whales travelling to and from southern Madagascar must take a route out of visual range of Cape Vidal.

Acoustic transects across the Mozambique Channel in July/August and September 1994 located singing humpback whales in mid-Channel, but otherwise only detected singers on the continental shelves of South Africa and Madagascar. This suggests that the migration stream travelling to and from Madagascar must take a route separate from the East African (or mid-Channel) stream. The sightings at Walters Shoal south of Madagascar in December 1988 and 1996 indicate that the area may be a 'staging post' (regular stopping place) for whales migrating south from Madagascar to the Antarctic. The fact that cows with calves formed an increasing number during the stay of the 'Vityaz' also indicates that this might be the tail of the migration, as this reproductive class is the last to leave the breeding grounds (Dawbin 1966). The lack of humpback whale sightings at Walters Shoal in late January 1974 from the 'Pieter Molenaar' would be consistent with the observations from the 'Vityaz', 'Shonan Maru' and 'Shonan Maru \# 2' representing the end of the southern migration through the area. Walters Shoal is situated on the Madagascar Ridge, which runs virtually north-south between the southern tip of Madagascar and about $40^{\circ} \mathrm{S}$. It is proposed that this is the principal route by which humpback whales travel to and from the Madagascar wintering ground in the southwest Indian Ocean. This route may be quite restricted in width, if the observations from the 'Shonan Maru' and 'Shonan Maru \# 2' are representative (Table 2 ).

This may be the easternmost migratory route of any size for southwest Indian Ocean humpback whales. Corbett (1994) failed to detect any humpback whales in October/November between Mauritius and southern Madagascar and referred to the paucity of sightings of the species at Mauritius itself. In December 1996 the 'Shonan Maru' and 'Shonan Maru \# 2' also failed to encounter any humpback whales between $46^{\circ}$ and $53^{\circ} \mathrm{E}$ (Table 2), although searching effort was limited in this area.

\section{(3) Central Mozambique Channel}

The existence of a third migratory stream for humpback whales in the southwest Indian Ocean was not 
suspected until the presence of singing whales was detected in the middle of the Mozambique Channel during acoustic transects in July/August and again in September 1994. It could be speculated that this is not a migration stream at all, but simply some wide-ranging individuals moving from, say, Mozambique to Madagascar within one breeding season. However, the juxtaposition of the singing whales on the eastward and westward transits across the channel would seem unlikely unless this was a migratory route of some kind. An isolated sighting of a cow-calf pair in the same vicinity in late November 1973 from the 'Pieter Molenaar' is some visual confirmation of the use of this route.

The winter destination of this migratory stream is uncertain. If it is assumed that the whales continued to migrate along the centre of the Mozambique Channel, more or less parallel with the coast, then they would encounter a number of small islands, atolls and banks, such as Ile Europa $\left(22^{\circ} 20^{\prime} \mathrm{S}\right)$, Jaguar Seamount $\left(22^{\circ} \mathrm{S}\right)$,

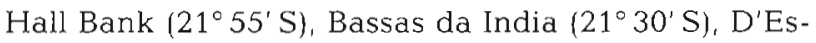
taing Bank (18 $\left.20^{\prime} \mathrm{S}\right)$ and I. Juan da Nova ( $\left.17^{\circ} \mathrm{S}\right)$. None of these has a surrounding shelf area larger than about $3 \mathrm{n}$ miles in diameter, and none would seem typical of a humpback whale wintering ground. At about $12^{\circ} 20^{\prime} \mathrm{S}$, however, lie the Isles Comores, with associated shelf areas extending about $120 \mathrm{n}$ miles in an east-west direction and $30 \mathrm{n}$ miles in a north-south direction. These, plus islands in the Aldabra group (at about $10^{\circ} \mathrm{S}$ ), could form a suitable habitat for overwintering humpback whales, and the recent sightings from these island groups at least confirm that they are utilised by humpback whales in the austral winter/spring.

Alternatively, this migratory stream could involve animals that are moving almost due north, converging on the East African coast in central Mozambique (at about $18^{\circ} \mathrm{S}$ ).

Unlike most of the acoustic stations held over the continental shelf of Mozambique or Madagascar, all 4 of the mid-Channel acoustic stations at which humpback whales were detected involved single (or on one occasion possibly 2) singers. This could reflect the differing environments (deep versus shallow water), but it is also possible that this migratory stream is relatively small in terms of numbers of participants.

\section{Conclusions}

The existence of 3 different migratory routes to and from winter breeding grounds in the southwest Indian Ocean does not necessarily imply that animals from each stream do not move between these 3 destinations, either within seasons or (more likely) between seasons. To establish the degree of such mixing would require the use of specific techniques, such as individual identification, satellite telemetry or genetic analysis.

The question of the northern limit to these migrations is not resolved by the data in this paper. Reeves et al. (1991) have discussed this point in some detail in the context of humpback whale sightings in the northern Indian Ocean, without coming to any firm conclusion whether the sightings could or could not represent transequatorial migrations by humpback whales from the southern hemisphere. More recent revelations of data arising from illegal Soviet catches before and after official protection was given to humpback whales suggest strongly that the whales in the Arabian Sea are on a northern hemisphere breeding season, and thus very probably separate from the 'African group' of southern humpbacks (Mikhaliev 1997).

The concentrations of humpback whales reported from merchant vessels in the Seychelles region (ca $5^{\circ} \mathrm{S}, 56^{\circ} \mathrm{E}$ ) in April and August (Slijper et al. 1964) have not been confirmed by aerial surveys from April to June (Keller et al. 1982), nor by observations from tuna vessels operating year-round in the vicinity of the Seychelles (Robineau 1991). The tuna vessel observers reported that humpback whales were 'rare' (being recorded only 10 or so times in a total of 964 sightings of 'balaenopterids' over $5 \mathrm{yr})_{i}$ during the months of July through October, when one would expect southwest Indian Ocean humpback whales to be at their furthest north, sightings of 'balaenopterids' were at their rarest. Consequently the validity of the identifications made from merchant vessels must be doubted, and the northern limit to the winter migration of southwest Indian Ocean humpback whales may be represented by the sightings in the Comores, at Aldabra and on the northeast tip of Madagascar, as documented by Reeves et al. (1991).

Acknowledgements. In a review such as this the authors are indebted to a whole host of people, most of whom have been acknowledged in the original publications. However we would like to reiterate our thanks for the contributions in general made by the spotter pilots for the Durban whaling station from 1972 to 1975, the crew and our colleagues on the 'Pieter Molenaar' in 1973/74, the observers and Earthwatch volunteers at Cape Vidal from 1988 to 1992, the Earthwatch volunteers and crew of the 'Zanj' in 1991 and 1994, and our colleagues and crew on the 'Shonan Maru' and 'Shonan Maru \# 2 ' in 1996/97. The Governments of Mozambique and Madagascar gave permission for the research to be carried out within their Exclusive Economic Zones, and the Natal Parks Board provided logistical support for the research at Cape Vidal. The loan of an inflatable boat by V. G. Cockcroft for the 1994 cruise to Madagascar is much appreciated. Financial support for this work came from a variety of sources, but special mention must be made for grants received from Earthwatch and the International Whaling Commission. P.B.B. acknowledges support from the Foundation for Research Development and the South African Marine Corporation. 


\section{LITERATURE CITED}

Angot M (1951) Rapport scientifique sur les expéditions baleinières autour de Madagascar (saisons 1949 et 1950). Mém Inst Scient Madagascar Sér A 6(2):439-486

Bermond M (1950) Campagne baleinière dans les eaux de Madagascar (saison 1949). Cybium 5:31-38

Best PB (1994) A review of the catch statistics for modern whaling in southern Africa, 1908-1930. Rep Int Whal Commn 44:467-485

Best PB, Ross GJB (1996) Whale observations from the Knysna Heads, 1903-1906. S Afr J Mar Sci 17:305-308

Best PB, Sekiguchi K, Rakotonirina BP, Rossouw A (1996) The distribution and abundance of humpback whales off southern Madagascar, August-September 1994. Rep Int Whal Commn 46:323-331

Chittleborough RG (1965) Dynamics of two populations of the humpback whale, Megaptera novaeangliae (Borowski). Aust J Mar Freshwat Res 16:33-128

Corbett HD (1994) The occurrence of cetaceans off Mauritius and in adjacent waters. Rep Int Whal Commn 44 393-397

Dawbin WH (1956) The migrations of humpback whales which pass the New Zealand coast. Trans R Soc NZ 84 $147-196$

Dawbin WH (1966) The seasonal migratory cycle of humpback whales. In: Norris KS (ed) Whales, dolphins and porpoises. University of California Press, Berkeley, p 145-170

Findlay KP (1989) The distribution of cetaceans of the coast of South Africa and South West Africa/Namibia. MSc thesis, University of Pretoria

Findlay KP, Best PB (1996a) Assessment of heterogeneity in sighting probabilities of humpback whales within viewing range of Cape Vidal, South Africa. Mar Mammal Sci 12(3): $335-353$

Findlay KP, Best PB (1996b) Estimates of the numbers of humpback whales observed migrating past Cape Vidal, South Africa, 1988-1991. Mar Mammal Sci 12(3):354-370

Findlay KP, Best PB, Peddemors VM, Gove D (1994) The distribution and abundance of humpback whales on their southern and central Mozambique winter grounds. Rep Int Whal Commn 44:311-320

Gambell R, Best PB, Rice DW (1975) Report on the Interna-

Editorial responsibility: Otto Kinne (Editor),

Oldendorf/Luhe, Germany tional Indian Ocean whale marking cruise 24 November 1973-3 February 1974. Rep lnt Whal Commn 25:240-252

Harmer SF (1931) Southern whaling. Proc Linn Soc Lond 142 $(1929-30): 85-163$

Keller RW, Leatherwood S, Holt SJ (1982) Indian Ocean cetacean survey, Seychelle Islands, April through June 1980. Rep Int Whal Commn 32:503-513

Lea $E$ (1919) Studies on the modern whale fishery in the Southern Hemisphere. Unpublished manuscript in British Museum (Nat. Hist.) files. Handwritten note on cover says 'received by the Falklands Islands Committee'

Mackintosh NA (1942) The southern stocks of whalebone whales. Discovery Rep 22:197-300

Mikhaliev YuA (1997) Humpback whales Megaptera novaeangliae in the Arabian Sea. Mar Ecol Prog Ser 149:13-21

Olsen $\varnothing$ (1914) Hvaler og hvalfangst I Sydafrika. Bergens Mus Årbok 1914-15 (5): 1-56

Rayner GW (1940) Whale marking: progress and results to December 1939. Discovery Rep 19:245-284

Reeves RR, Leatherwood S, Papastavrou V (1991) Possible stock affinities of humpback whales in the northern Indian Ocean. In: Leatherwood S, Donovan GP (eds) Cetaceans and cetacean research in the Indian Ocean Sanctuary. UNEP Marine Mammal Tech Rep 3:259-269

Robineau D (1991) Balaenopterid sightings in the western tropical Indian Ocean (Seychelles area), 1982-1986. In: Leatherwood S, Donovan GP (eds) Cetaceans and cetacean research in the Indian Ocean Sanctuary. UNEP Mar Mammal Tech Rep 3:171-178

Rosenbaum HC, Walsh PD, Razafindrakoto Y, Vely $M$, Desalle R (1997) First description of a humpback whale wintering ground in Baie d'Antongil, Madagascar Conserv Biol 11:312-314

Slijper EJ, Van Utrecht WL, Naaktgeboren C (1964) Remarks on the distribution and migrations of whales, based on observations from Netherlands ships. Bijdr Dierkd 34: $1-93$

Townsend $\mathrm{CH}$ (1935) The distribution of certain whales as shown by logbook records of American whaleships. Zoologica NY 19(1):1-50

Tyack P (1981) Interactions between singing Hawaiian humpback whales and conspecifics nearby. Behav Ecol Sociobiol 8:105-116

Submitted: August 1, 1997; Accepted: October 29, 1997

Proofs received from author(s): January 19, 1998 